\title{
Penggeseran Aspek Hukum Publik ke Aspek Hukum Privat (Bantuan Likuiditas Bank Indonesia)
}

\author{
Aang Achmad \\ Fakultas Hukum Universitas Pasundan Bandung \\ Jl. Lengkong Besar No. 68 Bandung \\ aangachmad@yahoo.com
}

\begin{abstract}
This research discusses the issues of obstacles in the settlement of Bank of Indonesia Liquidity Support criminal conduct. This research is a doctrinal or juridical normative research. The legal materials are collected through literary study and documentary study. The materials are then qualitatively analyzed. Through these methods, the research concludes that the delay of the settlement of Bank of Indonesia Liquidity Support criminal conduct caused by: (1) the system of criminal law that has formal-legalisticpositivistic character; (2) complex proof; (3) the absence of cooperation with states where the assets located; and (4) the not yet applied reverse proof.
\end{abstract}

Key words : Corruption, Bank of Indonesia Liquidity Support, Private Law

\begin{abstract}
Abstrak
Penelitian ini mengkaji permasalahan kendala-kendala dalam penyelesaian tindak pidana Bantuan Likuiditas Bank Indonesia. Penelitian ini adalah penelitian doktrinal atau yuridis normatif. Bahanbahan hukum dikumpulkan dengan studi kepustakaan dan studi dokumenter. Kemudian bahan-bahan tersebut dianalisis secara kualitatif. Dengan metode penelitian yang demikian, penelitian ini menyimpulkan bahwa lamanya penyelesaian tindak pidana korupsi Bantuan Likuiditas Bank Indonesia terkdala oleh antara lain (1) cara kerja sistem hukum pidana yang bersifat formal-legalistik-positifistik; (2) sulit pembuktiannya; (3) belum adanya kerjasama dengan semua negara di mana aset berada; dan (4) belum diterapkannya pembuktian terbalik.
\end{abstract}

Kata kunci : Korupsi, Bantuan Likuiditas Bank Indonesia (Bank of Indonesia Liquidity Support), hukum perdata 


\section{Pendahuluan}

Kucuran dana Bantuan Likuiditas Bank Indonesia (BLBI) oleh bank penerima dana didasarkan atas kebijakan pemerintah akibat adanya krisis moneter 1997/1998 dengan tujuan untuk memulihkan atau menyelamatkan stabilitas perekonomian negara yang diselewengkan, ternyata tidak dipergunakan sesuai tujuan dan tidak dikembalikan dalam tempo yang ditentukan.

Tetapi sebaliknya, justru dipergunakan untuk kepentingan pribadi dengan kelompoknya (melibatkan para pejabat negara), untuk itu negara telah dirugikan dan akibatnya goncangan perekonomian bangsa bertambah hebat.

Penyelesaian kasus tersebut tidak dapat diselesaikan melalui KUHP. KUHP sebagai hukum positif ternyata tidak dapat menyelesaiakan tindak pidana korupsi secara tuntas. Untuk itu diperlukan ketentuan hukum di luar KUHP. Karena tindak pidana korupsi merupakan tindak pidana luar biasa, maka harus diselesaikan secara luar biasa pula. ${ }^{1}$

Undang-Undang No. 3 Tahun 1971 tentang Pemberantasan Tindak Pidana Korupsi (UUPTPK) sebagai pengganti Undang-Undang No. 24 Prp Tahun 1960 tentang Pengusutan, Penuntutan, Pemeriksaan Tindak Pidana Korupsi, pada praktiknya juga tidak dapat menyelesaikan kasus BLBI karena terbentur dengan asas legalitas yang bersifat legal-positifistik (kaku) sehingga sulit dalam

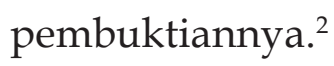

Oleh karenanya, Undang-Undang Nomor 3 Tahun 1971 diganti dengan UndangUndang Nomor 31 Tahun 1999 jo Undang-Undang Nomor 20 Tahun 2001. Undangundang tersebut memuat beberapa pembaharuan hukum yang luar biasa, antara lain pemanfaatan aspek perdata dalam pemberantasan tindak pidana korupsi sebagaimana dituangkan dalam Pasal 32. Menurut pendapat penulis, telah terjadi pergeseran aspek hukum yang signifikan, yakni pergeseran aspek hukum publik ke aspek hukum privat, sekalipun implementasinya belum maksimal.

\footnotetext{
${ }^{1}$ Romli Atmasasmita, Sekitar Masalab Korupsi, Mandar Maju, Jakarta, 2004, hlm. 9

${ }^{2}$ Muladi dan Barda Nawawi, yang mengutip pendapat Don C. Gibbson, tipologi kejahatan dengan karakteristik "law visibility" yang mencakup pelbagai dimensi lapangan kerja (notaris, wartawan, pengacara dan lain-lain). Contohnya yang dahulu adalah diajukannya seseorang akuntan publik yang berkolusi dengan wajib pajak untuk meringankan pajak dan merugikan keuangan negara.

Begitu pula, beberapa waktu yang lalu (sekitar tanggal 26 Agustus 1996), bank Indonesia, sebagai Bank Central Indonesia, kebobolan sekitar Rp. 3 milyar sebagai akibat perbuatan managerial profesional internal yang bekerja sama dengan perusahaan suasta yang mengakibatkan kerugian keuangan negara.
} 
Pembaharuan selanjutnya adanya perluasan pengertian tentang sifat melawan hukum yang dijabarkan dalam penjelasan Pasal 2 ayat (1), yakni mempertegas pengertian sifat melawan hukum formil dan materiil, yang dapat dijadikan acuan untuk memberikan sanksi kepada para pelaku korupsi dengan mendasarkan pada asas ultimum remedium. ${ }^{3}$

\section{Rumusan Masalah}

Berdasarkan uraian di atas, dapat dirumuskan suatu masalah yang mendasar, yaitu: aspek hukum apakah yang mampu menyelesaikan tindak pidana korupsi yang dilakukan oleh para obligator BLBI selaku penerima dana bantuan BI dalam penyehatan bank-bank yang bermasalah pada waktu krisis moneter pada 1997 dalam memenuhi rasa keadilan masyarakat, serta kendala-kendala hukum apakah yang mempengaruhinya, sehingga penyelesaian kasus BLBI tersebut berlarut-larut? Selanjutnya dapat diidentifikasikan sebagai berikut: 1. Aspek Hukum Perdata yang bagaimanakah yang mampu dan efektif dalam penyelesaian tindak pidana korupsi yang dilakukan oleh para obligor BLBI selaku penerima kucuran dana dari BI, sehingga tercipta rasa keadilan masyarakat? 2. Kendala hukum apakah yang mempengaruhinya, sehingga penyelesaian kasus BLBI tersebut berlarut-larut?

\section{Tujuan Penelitian}

Penelitian bertujuan untuk mengetahui aspek hukum perdata yang mampu dan efektif dalam penyelesaian tindak pidana korupsi yang dilakukan oleh para obligor BLBI selaku penerima kucuran dana dari BI, sehingga tercipta rasa keadilan masyarakat. Di samping itu, kendala hukum yang mempengaruhinya, sehingga penyelesaian kasus BLBI tersebut berlarut-larut

\section{Metode Penelitian}

Berdasarkan latar belakang dan tujuan penelitian yang telah diuraikan di atas, dalam melakukan penelitian ini digunakan metode penelitian secara spesifik yakni

${ }^{3}$ Sudarto dalam Agus Rahajo, Perkembangan Ajaran Sifat Melawan Hukum Material dalam Hukum Pidana Indonesia, http://www. unsoed.ac.id/newcmsfak/UserFiles/File/HUKUM/Agus, dimuat pula dalam bukunya Romli 
penelitian yang bersifat deskriptifanalitis, yaitu menggambarkan tentang aspek hukum apa yang dapat dipergunakan untuk menanggulangi tindak pidana korupsi dalam kasus BLBI, kemudian dianalisis melalui metode pendekatan yuridis normatif, yaitu diteliti melalui hukum sebagai norma positif dengan menggunakan metode penafsiran atau interpretasi gramatikal, interpretasi sistematis, interpretasi autentik, interpretasi historis, dan interpretasi ekstensif.

Penelitian ini dilakukan melalui penelitian kepustakaan untuk mendapatkan Data Sekunder dengan menggunakan bahan hukum primer, bahan hukum sekunder, dan bahan hukum tertier, sedangkan penelitian lapangan guna mengambil data primer yang berada di instansi-instansi yang terkait dengan penelitian ini, hanya sebagai penunjang data sekunder yang didukung dengan melakukan wawancara, berdasarkan daftar pertanyaan yang telah disusun sebelumnya, dengan melibatkan para pejabat dalam instansi yang terkait, pakar hukum, praktisi hukum dan para akademisi demi kelengkapan data sekunder dalam penelitian ini.

Selanjutnya data yang diperoleh akan dianalisis dengan metode kualitatif, artinya dianalisis dengan tidak menggunakan angka-angka atau perhitungan statistik, tetapi berupa suatu gambaran tentang aspek hukum apa yang dapat dipergunakan dalam penanggulangan tindak pidana korupsi dalam perkara BLBI. Kemudian setelah dianalisis, baru kemudian pada akhirnya penulis mengambil kesimpulan dengan memberikan rekomendasi.

\section{Hasil Penelitian dan Pembahasan}

\section{Upaya Memberantas Korupsi di Indonesia Melalui Pembaharuan Hukum Pidana Positif Dalam Mencegah Timbulnya Kerugian Negara.}

1976-1998 merupakan titik puncak praktik korupsi yang dilakukan oleh para banker, ${ }^{4}$ ketika negara Indonesia sedang mengalami krisis moneter yang luar biasa, hingga sulit memulihkan kondisi perekonomian di Indonesia. Pemerintah memberikan kucuran dana khususnya kepada bank-bank besar yang kemungkinan masih bisa diselamatkan, yaitu melalui Bantuan Likuidasi Bank Indonesia (BLBI).

${ }^{4}$ Lobby Loqman, Beberapa Ikhwal Dalam Undang-Undang No. 3 Tahun 1971 Tentang Pemberantasan Tindak Pidana 
Maksud baik pemerintah tersebut kemudian diselewengkan, BLBI dipergunakan untuk kepentingan para pemegang saham pengendali (memperkaya diri sendiri) sehingga setelah dikaji tindakan para obligor merugikan keuangan negara yang berakibat tambah terpuruknya kondisi perekonomian negara yang pada akhirnya mengganggu stabilitas nasional.

Dalam kasus BLBI, para penegak hukum sulit untuk membuktikan unsur "kejahatan dan pelanggaran" nya sendiri semata-mata dikarenakan karakteristik para pelaku korupsi untuk memanipulasi asas dan prinsip-prinsip hukum yakni yang bersembunyi dibalik asas praduga tidak bersalah (presumption of inosence), ${ }^{5}$ atau bahkan berlindung pada asas legalitas, karena melaksanakan aturan yang dikeluarkan pemerintah, menyalahkan aturan yang ada (multi tafsir), protes terhadap aturan yang ada hingga mengajukan proses uji konstitusi, bahkan menuduh balik penegak hukum melakukan kejahatan yang sama dengan pelaku, mencemarkan nama baik, fitnah, hingga menuduh balik penegak hukum melanggar HAM. Di samping itu juga kasus BLBI sarat dengan muatan politik, serta celakanya uang hasil korupsi banyak disimpan di luar negeri.

Menurut Nigel Walker proses penanggulangan kejahatan dapat dilakukan melalui tiga cara, yakni melalui cara penerapan hukum pidana (criminal law aflication), melalui tanpa pidana atau non penal (prevention without punishment), dan campuran dari keduanya. ${ }^{6}$ Saya sependapat dengan Nigel Walker, bahwa penyelesaian kasus BLBI dengan cara campuran dari keduanya, dengan memperhatikan asas ultimum remidium yang menyebutkan bahwa penerapan pidana merupakan upaya terakhir. ${ }^{7}$ Lebih lanjut Niegel Walker mengatakan “Hukum Pidana jangan digunakan apabila kerugian atau bahaya yang timbul lebih besar dibanding dengan perbuatannya sendiri", dapat dijadikan tolak ukur dalam mencari alternatif penyelesaiaan tindak pidana korupsi, khususnya penyelesaian kasus BLBI.

Maka, menjadi tepat apabila UUPTPK kemudian diganti dengan UndangUndang Nomor 31 Tahun 1999 jo Undang-Undang Nomor 20 Tahun 2001 dengan berbagai pembaharuan yang luar biasa, antara lain memuat secara tegas mengenai pengertian sifat melawan hukum formil dan materiil, dimuatnya aturan hukuman hlm. 17.

${ }^{5}$ Indriyanto Seno Adji, Korupsi, Kebijakan Aparatur Negara dan Hukum Pidana. CV Diedit Media, Jakarta, 2007,

${ }^{6}$ Niegel Walker, Sentencing in a Rational Society, New York, 1972, p. 15.

${ }^{7}$ Romli Atmasasmita, Sekitar Masalah Korupsi, Op.Cit 
mati, mengatur tentang batas minimun sanksi pidana penjara dan denda yang sifatnya kumulatif, mengatur juga tentang pembuktian terbalik, dan dimuatnya aturan tentang pemanfaatan hukum perdata dalam penyelesaian pengembalian aset atau kerugian negara yang dikorupsi, selain itu juga memperbolehkan penggunaan sarana elektronik sebagai alat bukti, serta adanya peran serta masyarakat dalam proses pemberantasan tindak pidana korupsi. ${ }^{8}$ Oleh karenanya, saya berpendapat bahwa tujuan dari pembaharuan hukum pidana yang luar biasa tersebut adalah selain untuk mempermudah pembuktian juga memberikan pilihan penyelesaian tindak pidana korupsi dengan memperhatikan asas ultimum remidium.

Selanjutnya, UU No. 31 Tahun 1999 jo UU No. 20 Tahun 2001 memberikan perluasan terhadap subyek hukum dalam tindak pidana korupsi mencakup pegawai negeri dalam arti luas dan perseorangan serta korporasi. ${ }^{9}$ Hal ini secara filosofi bertujuan agar dapat mengakomodir segala bentuk modus operandi dalam tindak pidana korupsi yang dilakukan oleh setiap orang sehingga mudah dalam pembuktiannya. Untuk itu, pembaharuan dan atau perubahan hukum pidana yang mengatur tindak pidana korupsi berlaku asas Lex Specialis Legi Lex Generalis ketika menjadi aturan baru. ${ }^{10}$ Namun demikian dalam praktiknya tetap belum menyelesaikan kasus BLBI secara tuntas.

Perluasan arti sifat melawan hukum (materiil) sesungguhnya merupakan terobosan hukum dengan tujuan seperti yang telah saya sampaikan di atas ternyata menimbulkan perdebatan di antara para penegak hukum dan para pakar hukum yang berfikir normatif dan cenderung formal-positifistik (tidak progresif). Akhirnya muncul Putusan Mahkamah Konstitusi Republik Indonesia (MKRI) Nomor 003/ PPU-IV/2006 yang intinya menyebutkan bahwa "Penjelasan Pasal 2 ayat (1) UU No. 31 Tahun 1999 bertentangan dengan UUD Negara RI 1945 dan menyatakan tidak mempunyai kekuatan hukum mengikat". Putusan tersebut dapat menyulitkan penyidik dan penuntut umum dalam memproses tindak pidana korupsi. Namun

\footnotetext{
${ }^{8}$ Dalam konsideran Penjelasan Undang-Undang No. 31 Tahun 1999 tentang Pemberantasan Tindak Pidana Korupsi.

${ }^{9}$ Lihat Pasal 1 ayat (2 dan 3) yang menyebutkan : ayat (2) Pegawai Negeri adalah meliputi : a. pegawai negeri sebagaimana dimaksud dalam undang-undang tentang Kepegawaian; b. pegawai negeri sebagaimana dimaksud dalam Kitab Undang-Undang Hukum Pidana; c. orang yang menerima gaji atau upah dari keuangan negara atau daerah; d. orang yang menerima gaji atau upah dari suatu korporasi yang menerima bantuan dari keuangan negara atau daerah; atau e. orang yang menerima gaji atau upah dari korporasi lain yang mempergunakan modal atau fasilitas dari negara atau masyarakat. ayat (3) Setiap orang adalah orang perseorangan atau termasuk korporasi.

${ }^{10}$ Barda Nawawi Arief, Pembaharuan Hukum Pidana (Dalam Perspektif Kajian Perbandingan), Citra Aditya Bhakti, Bandung, 2005, hlm. 29.
} 
demikian apabila menyimak kalimat dalam Putusan MK “tidak mempunyai kekuatan hukum mengikat" tersebut bukan berarti Penjelasan Pasal 2 ayat (1) kemudian sama sekali tidak dapat diterapkan, tergantung kepada keberanian para penegak hukum dalam menuntaskan kasus-kasus korupsi yang menjamur di Indonesia.

Berkaitan dengan hal itu Indonesia meratifikasi konvensi Internasional Anti Korupsi Sedunia (UNCAC) 2003, ${ }^{11}$ yang disahkan melalui Undang-Undang No. 7 Tahun 2006. Dalam konggres International Penal Reform Conference" yang diselenggarakan di Royal Holloway College, University of London, pada tanggal 1317 April 1999 dikemukakan, bahwa salah satu unsur kunci dari agenda baru pembaharuan hukum pidana (the key elements of a new agenda for penal reform) ialah perlunya memperkaya sistem peradilan formal dengan sistem atau mekanisme informal dalam penyelesaian sengketa yang sesuai dengan standar-standar hak asasi manusia (the need to enrich the formal judicial system with informal, locally based, dispute resolution mechanisms which meet human rights standards), dengan strategi pengembangan dalam melakukan pembaharuan hukum pidana, antara lain: 1 . Restorative justice; 2. Alternative dispute resolution; 3. Informal justice; 4 . The role of civil society in penal reform. ${ }^{12}$

Mengembangkan Alternative Disputes Resolution (ADR) dan Restorative Justice ${ }^{13}$ yaitu sebagai konsep yang diambil dari dan bersumber nilai-nilai yang berkembang di masyarakat, maka menjadi tepat apabila Pasal 2 ayat (1) tetap dipertahankan atau dipergunakan sebagai dasar untuk memberikan sanksi kepada para pelaku korupsi.

Restorative Justice dan ADR merupakan suatu konsep yang terbuka dalam bentuk implementasinya, artinya dalam pandangan cara bekerja konsep tersebut, sehingga

${ }^{11}$ UNCAC diadopsi oleh Majelis Umum PBB berdasarkan resolusi 58/ 4 tanggal 31 Oktober 2003; UNCAC telah diratifikasi oleh Pemerintah Republik Indonesia berdasarkan Undang-undang Republik Indonesia Nomor 7 Tahun 2006 tentang Pengesahan (Konvensi Perserikatan Bangsa-bangsa Anti Korupsi, 2003) pada tanggal 18 April 2006. Untuk penyebutan Konvensi ini, Penulis menggunakan UNCAC.

${ }^{12}$ Ibid., hlm. 14

${ }^{13}$ http://www.jurnas.com/news/25205/Koruptor Rp25 Juta Bisa Dibebaskan//Nasional/Hukum : Dalam Rancangan Undang-Undang Tindak Pidana Korupsi (Tipikor) tercantum pasal yang menyebutkan korupsi di bawah Rp25 juta bisa diampuni dengan syarat mengembalikan uang tersebut. Kontan saja, banyak pihak tak setuju dengan aturan baru yang tengah digodok tersebut. Namun Wakil Jaksa Agung, Darmono punya pendapat berbeda. "Itukan pemikiran yang kedepannya terkait dengan masalah penyederhaaan, restorative justice system. Jadi tidak semua tindak pidana diselesaikan di pengadilan, jadi ada langkah-langkah hukum lainnya," ujar Darmono, Jumat (8/4) di Kejagung Jakarta. 
akan lebih dapat dirasakan keadilannya. Sebagai alternatif, Restorative Justice dititikberatkan pada akibat dari tindak pidana korupsi, yaitu adanya kerugian negara dan mengganggu stabilitas nasional. Akibat tindak pidana korupsi yang dapat merugikan keuangan negara tersebut harus segera dipulihkan serta mengurangi kerugian di masa mendatang, sehingga dapat berfungsi juga sebagai pencegahan kejahatan.

Maka menjadi relevan ketika Dwidja Priyatno mengatakan bahwa penjatuhan sanksi pidana sesungguhnya harus dilihat dari tujuannya, karena hal itu sangat dipengaruhi oleh filsafat yang dijadikan dasar pengancaman dan penjatuhan pidananya, mengingat penjatuhan pidana terhadap para pelaku koruptor tidak menjadikan jera baginya. ${ }^{14}$

Satjipto Rahardjo menyebutkan "untuk menciptakan good corporate governance, agar dapat memenuhi rasa keadilan masyarakat maka tidak cukup hanya membenahi peraturan dan lembaganya saja, tetapi harus tetap memperhatikan unsur budaya hukum". ${ }^{15}$ Artinya tidak saja budaya hukum masyarakatnya, tetapi juga budaya hukum para penegak hukum itu sendiri, maka diperlukan pembinaan hukum yang berkesinambungan dan meningkatkan pengawasan terhadap kinerja para penegak hukum tersebut. Selanjutnya Satjipto Rahardjo dalam bukunya yang berjudul Membedah Hukum Progresif mengemukakan bahwa kegagalan dalam penegakan dan pemberdayaan hukum ini ditengarai oleh sikap submissive terhadap kelengkapan hukum yang ada seperti prosedur, doktrin, dan asas hukum itu sendiri, selain ketidakmampuan criminal justice system dengan mengemban tugasnya. ${ }^{16}$

\section{Aspek Perdata dalam Penyelesaian Tindak Pidana Korupsi Para Obligor BLBI dalam Usaha Menciptakan Rasa Keadilan Masyarakat}

Berdasarkan Pasal 4, 18, 32, 33, 34 dan Pasal 38 UU PTPK, serta dalam article 31 United Nations Convention Against Corruption (UNCAC) 2003 tentang pembekuan, perampasan dan penyitaan (freezing, seizure and confiscation), article 40 UNCAC 2003 ini sebagai landasan menembus kerahasiaan Bank (Bank Secrecy), dan article 43 UNCAC 2003 dalam Chapter IV yang mengatur tentang kerjasama internasional, dan ketentuan dalam Chapter $\mathrm{V}$ tentang pengembalian asset (Asset Recovery) dan Pasal

${ }^{14}$ Dwidja Priyatno, Jurnal RESTORASI, edisi VIII/volume III, 2007, hlm. 03-04.

${ }^{15}$ Satjipto Rahardjo, Modernisasi dan Perembangan Kesadaran Hukum Masyarakat, Jurnal Masalah-masalah Huk.um, FH Undip, No.1-6 Tahun X, 1980, hlm. 18.

${ }^{16}$ Satjipto Rahardjo, Membedah Hukum Progresif, Kompas, Jakarta, 2006, hlm. x. 
63 ayat (2) Undang-Undang No. 7 Tahun 2006 (UU 7/2006) tentang Pengesahan United Nations Convention Against Corruption, $2003^{17}$ merupakan dasar bagi pemanfaatan aspek perdata dalam Penyelesaian Tindak Pidana Korupsi di Indonesia, khususnya dapat dijadikan pijakan dalam percepatan pengembalian aset negara atau pemulihan aset negara, baik yang berada di wilayah korban (Indonesia) atau juga yang di bawa ke luar negeri oleh para koruptor.

Sejalan dengan hal tersebut sebagaimana makna asas ultimum remidium bahwa upaya represif merupakan upaya terakhir apabila upaya lainnya tidak mampu untuk menyelesaikan kasus BLBI, merupakan suatu pendekatan yang perlu dioptimalkan selain asas oportunitas.

Dalam menyelesaikan perkara tindak pidana korupsi seperti kasus BLBI, kasus Centuri atau kasus-kasus korupsi besar lainnya yang dilakukan dalam keadaan tertentu, pemerintah (red. para penegak hukum) dihadapkan kepada dua mata pisau yang sama tajamnya, ketika berhadapan dengan proses penegakan hukumnya. Satu sisi kejahatan tersebut dapat dikatagorikan sebagai kejahatan yang mengarah langsung pada stabilitas keuangan (perekonomian) negara yang mengancam kesejahteraan rakyat, yang harus segera diproses guna pemulihan aset negara, di sisi lain, sebagai kejahatan biasa yang dilakukan oleh para pejabat, pegawai negeri, perseorangan atau korporasi yang dilakukan baik di tingkat pusat maupun daerah, dengan menyalahgunakan keadaan, jabatan, fasilitas negara, system politik dan hukum, termasuk proses dan mekanisme kerjanya, yang memanfaatkan latar belakang dan situasi politik.

Banyak para koruptor (melalui penal) kemudian lolos (SP3), karena cara mereka memanipulasi hukum, atau mungkin dari para penegaknya sendiri yang menyimpang, maka aspek perdata dalam hal ini mempunyai peran sebagai usaha pengembalian aset negara atau pemulihan aset dalam kasus BLBI maupun kasuskasus korupsi lainnya, guna menciptakan good corporate governance, sehingga masyarakat dapat segera memperbaiki kesejahteraannya. Karena masalah korupsi sudah merupakan ancaman serius terhadap stabilitas, ${ }^{18}$ dan keamanan masyarakat

${ }^{17}$ Pasal 66 ayat (2) mengatur tentang penyelesaian perselisihan antara negara pihak yang tidak dapat diselesaikan melalui jalur negosiasi. Menurut ketentuan ini, sengketa negara pihak mengenai penafsiran atau penerapan konvensi wajib diajukan pada Mahkamah Internasional (International Court of Justice) dengan permohonan sesuai dengan statute pengadilan.

${ }^{18}$ Romli Atmasasmita, Strategi dan Kebijakan Pemberantasan Korupsi Pasca Konvensi PBB Menentang Korupsi Tahun 2003: Melawan Kejahatan Korporasi, Paper, Jakarta, 2006, hlm. 1. 
nasional dan internasional, ${ }^{19}$ telah melemahkan institusi, nilai-nilai demokrasi dan keadilan serta membahayakan pembangunan berkelanjutan ${ }^{20}$ maupun penegakan hukum. ${ }^{21}$

Pemanfaatan aspek perdata menjadi solusi bagi pemerintah untuk segera mengembalikan aset-aset yang dicuri oleh para koruptor. Maka menjadi relevan pendapat Jeremy Bentham dan Niegel, yang mengatakan bahwa hukum pidana janganlah digunakan apabila tanpa dasar (groundless), tidak menguntungkan. (needless), tidak efisien (in efficiens) dan tidak berguna ( un profitable). ${ }^{22}$

Menurut Undang-Undang No. 4 Tahun 2004 jo No. 48 Tahun 2009 tentang Kekuasaan Kehakiman (UU Kehakiman), pada prinsipnya penyelesaian sengketa perdata dapat diselesaikan melalui jalur peradilan (litigasi) atau di luar jalur peradilan (non litigasi). Ternyata penggunaan mekanisme perdata melalui jalur litigasi masih dirasa sulit, sehingga pemerintah mencari solusi dalam menyelesaikan kasus BLBI tersebut, yaitu dengan membentuk Badan Penyehatan Perbankan Nasional (BPPN) melaui Kepres No. 27 Tahun 1998 yang bertugas untuk melakukan penyehatan perbankan, penyelesaian aset bermasalah, dan mengupayakan pengembalian uang negara yang tersalur pada sektor perbankan. Namun demikian dari 1998 hingga 2002 BPPN belum membuahkan hasil yang maksimal, diperlukan cara lain agar aset negara segera kembali guna memperbaiki stabilitas nasional, maka cara non-litigasi menjadi salah satu pilihannya.

Untuk itu Megawati mengeluarkan Inpres No. 8 Tahun 2002 tentang release and discharge sebagai tindak lanjut dari Tap MPR No. VI/MPR/2002 tentang Rekomendasi atas Laporan Pelaksanaan Putusan MPR RI oleh Presiden, DPA, DPR, BPK, MA pada Sidang Tahunan MPR RI Tahun 2002 yang menginstruksikan kepada BPPN untuk segera mengambil langkah bagi penyelesaian kewajiban pemegang saham dalam rangka penyelesaian seluruh kewajibannya melalui BPPN, untuk itu dilakukan negosiasi agar para pemegang saham sepakat memilih bentuk mekanisme penyelesaian kewajiban, antara lain dalam bentuk Master of Settlement and Acquisition

\footnotetext{
${ }^{19}$ Romli Atmasasmita, Strategi dan Kebijakan Hukum dalam Pemberantasan Korupsi Melawan Kejahatan Korporasi di Indonesia: Membentuk Ius Constituendum Pasca Ratifikasi Konvensi PBB Menentang Korupsi Tabun 2003, Paper, Jakarta, 2006, hlm. 1.

${ }^{20}$ Romli Atmasasmita, Indonesia Pasca Konvensi PBB Menentang Korupsi, Paper, Jakarta, 2006, hlm.5.

${ }^{21}$ Romli Atmasasmita, Strategi Pencegahan dan Pemberantasan Korupsi di Sektor Swasta dalam Lingkup Konvensi PBB Anti Korupsi 2003, Paper, Jakarta, 2006, hlm. 7.

${ }^{22}$ Jeremy Bentham, Teori Perundang-undangan, Nusamedia dan Nuansa, Bandung, hlm. 109. Lihat Niegel Walker, 1972, Sentencing in a Rational Society, New York, 2006, p. 15.
} 
Agreement adalah perjanjian Penyelesaian BLBI dengan jaminan aset (MSAA), Master of Refinancing and Note Issuence Agreement suatu perjanjian penyelesaian BLBI dengan jaminan aset dan jaminan pribadi (MIRNA), atau dengan menandatangani Akta Pengakuan Utang (APU) tenggang waktu yang ditetapkan oleh Komite Kebijakan Sektor Keuangan (KKSK), ${ }^{23}$ yang selanjutnya pemerintah akan mengeluarkan Surat Keterangan Lunas (SKL) sebagai alasan penghentian penanganan aspek pidananya, dengan jaminan SP3 dari Jaksa Agung. Menurut Takdir Rachmadi, meknisme tersebut berkaitan dengan prospek pengembangan dan penganekaragaman pilihan cara penyelesaian sengketa bagi masyarakat. ${ }^{24}$

Inpres tersebut sesungguhnya bertujuan untuk mempercepat pengembalian kerugian negara atau aset negara ditangan para Pemegang Saham tersebut, guna mempercepat perbaikan kesejahteraan masyarakat.

Pola penyelesaian BPPN tersebut antara lain menggunakan skema Penyelesaian Kewajiban Pemegang Saham (PKPS), yang diistilah release and discharge sebenarnya tidak dikenal dalam pranata hukum Indonesia, tetapi lazim digunakan di negara yang menganut sistem hukum common law. Meskipun demikian Release and discharge yang dimuat dalam perjanjian antara BPPN dengan para konglomerat atau obligor yang mempunyai kewajiban kepada BPPN berdasarkan perjanjian Penyelesaian Kewajiban Pemegang Saham (PKPS), baik yang berbentuk MSAA, MRNIA atau APU, melalui BPPN. Pemerintah menggulirkan pilihan cara penyelesaian tersebut, sematamata ingin segera adanya penyelesaian terhadap para debitur yang bermasalah. ${ }^{25}$

Maksud baik tersebut kemudian ditentang oleh sebagian kalangan ahli hukum dan NG'O, namun demikian mendapat dukungan dari Mahkamah Agung Republik Indonesia sebagaimana dituangkan dalam Putusannya tertanggal 30 Desember 2003 No. 06/G/HUM/ 2003 tentang Pemberian Jaminan Kepastian Hukum kepada debitur yang bermasalah. ${ }^{26}$ Menurut pendapat penulis yang didasarkan kepada teori Satjipto Rahardjo tentang pemikiran "hukum progresif", sehingga penilaian keberhasilan hukum tidak dilihat dari diterapkannya hukum materiil maupun formal, melainkan dari penerapannya yang berani, bermakna dan berkualitas, yaitu adanya keinginan

\footnotetext{
${ }^{23}$ Mekanisme MSAA, MRNIA, dan release and discharge dapat disebut sebagai pola negosiasi karena mengandung proses tawar-menawar dan karena itu kesepakatan, meskipun posisi tawar para obligor lebih lemah.

${ }^{24}$ Takdir Rachmadi dalam Basuki Rekso Wibowo, Pidato Pengukuhan jabatan Guru Besar Di Bidang ilmu Hukum: Menyelesaiakan Sengketa Bisnis Di Luar Pengadilan, Universitas Airlangga, 17 Desember 2005, hlm. 6-7.

${ }^{25}$ Kompas, Perlu Mekanisme Atasi Hambatan, 27 Oktober 2007, hlm. 2.

${ }^{26}$ http://www.hukumonline.com/berita/baca/hol17428/lagi-putusan-ma-salah-ketik
} 
segera dapat mengembalikan situasi perekonomian saat itu (pasca krisis moneter) ${ }^{27}$ Maka menjadi wajar ketika korupsi yang dilakukan oleh para koruptor secara berani tersebut, kemudian penyelesaiannya juga dilakukan secara berani yakni dengan secara out of court settlement yang menggunakan sarana ADR, yang nota bene hukum formal (UUPTPK) tidak mengaturnya. Selain itu juga dapat memberikan kepastian hukum dalam pengembalian kerugian keuangan negara dengan mengesampingkan prosedur hukum pidana maupun perdata (litigasi).

Kemudian dengan telah melakukan pembayaran secara keperdataan dan telah pula dikeluarkan SKL tersebut ternyata menurut Pasal 1381 BW, serta Pasal 1853 KUH Perdata (BW) dan Pasal 4 dan Pasal 18 ayat (1) UU PTPK bukan berarti menghilangkan tanggung jawab dalam lapangan hukum pidananya. Namun tindakan pemerintah yang berani tersebut baik langsung maupun tidak langsung memberikan solusi bagi penyelesaian kasus BLBI, hal ini merupakan suatu terobosan hukum yang berani yang dilakukan pemerintah, semata-mata demi pemulihan kesejahteraan rakyat yang terkena krisis multidimensi.

Pola penyelesaiaan melalui Inpres No. 8 Tahun 2002 tentang (Release and Dischage atau pelepasan dan pengapusan) pada masa pemerintahan Megawati inilah yang pada akhirnya berhasil mengembalikan aset-aset negara hingga puluhan trilyunan rupiah, walaupun perluasan dari kasusnya sendiri hingga saat ini belum tuntas.

Menyikapi hal ini penulis berpendapat bahwa pola negosiasi dapat diistilahkan dengan golden handshake dapat menjadi salah satu jalan ke luar dalam mempercepat penyelesaian tindak pidana korupsi selain menggunakan proses pidana.

Kemudian untuk pengambilan aset negara yang berada di luar negeri dapat dilakukan yang didasarkan kepada ketentuan dalam Bab $\mathrm{V}$ tentang pengembalian asset (Asset Recovery) UNCAC, ${ }^{28}$ tentunya dengan meningkatkan hubungan diplomatik antara negara Indonesia dengan negara lain tempat aset negara tersebut berada (seandainya perjanjian extradisi belum ada), yaitu melalui sarana Mutual Legal Assistance in Criminal Matters (MLA) atau Bantuan Hukum Timbal Balik di bidang pidana dengan berbagai negara ${ }^{29}$ yang diatur dalam Undang-Undang No. 1

\footnotetext{
${ }^{27}$ Satjipto Rahardjo, Loc. Cit

${ }^{28}$ http://www.komisihukum.go.id/index.php?option=com content\&view=article\&id $=83 \% 3 \mathrm{~A}$ pendapatkhn-tentang-stolen-asset-recovery-star Anitiative \&catid $=37 \% 3$ Aopini\&Itemid $=61 \&$ lang $=$ in

${ }^{29}$ Dalam Chapter IV UNCAC, Negara Pihak wajib untuk membantu satu sama lain dalam setiap aspek perjuangan melawan korupsi, termasuk pencegahan, investigasi dan penuntutan pelanggar. Penekanan khusus diletakkan pada bantuan hukum timbal balik, dalam pengumpulan dan mentransfer bukti untuk digunakan di pengadilan, dan
} 
Tahun 2006 tentang Bantuan Timbal Balik yang mengatur tentang prosedur Mutual Assistance Request (MAR) atau permohonan bantuan hukum dan pembagian hasil tindak pidana yang disita kepada negara yang membantu.

Berkaitan dengan pengembalian aset (Asset Recovery), UNCAC, Pasal 43, Ketentuan yang dimuat dalam Bab V, dan Pasal 31 UNCAC mengatur tentang percepatan proses Stolen Asset Recovery (StAR) terhadap negara yang sedang menghadapi permasalahan pidana (korupsi) yang berkaitan dengan aset-aset negara yang dibawa atau ditanam di luar negeri. Perampasan aset negara yang ditinggalkan pelaku korupsi ke luar negeri sesungguhnya dapat dilakukan tanpa pemidanaan, hal yang demikian di dalam bukunya Greenberg, Theodore S. yang berjudul Stolen Asset Recovery, Good Practice Guide Untuk Perampasan Aset Tanpa Pemidanaan (NonConviction Based/NCB Asset Forfeiture) disebut dengan istilah "Perampasan Aset NonConviction Based (NCB) atau Tanpa Pemidanaan". ${ }^{30}$

Ketentuan tersebut telah diatur dalam Pasal 18 ayat (1) UU PTPK dapat diberlakukan dan diterapkan dalam menangani kasus korupsi, mengingat fenomena yang terjadi belakangan ini, yaitu hasil korupsi (aset negara yang dicuri) di transfer ke luar negeri, yang diikuti kepindahan kewarganegaraan koruptor sehingga tidak memungkinkan lagi tersentuh oleh hukum nasional, maka negara di mana barang atau aset negara korban (Indonesia) berada dan telah diduga bahwa barang tersebut hasil kejahatan, maka negara yang bersangkutan dapat melakukan tindakan perampasan terhadap barang atau aset (NCB) tersebut tanpa dilakukan pemidanaan terhadap pelaku (koruptor) tersebut.

Selain itu, terhadap barang-barang yang ditinggalkan di negara korban (Indonesia) meskipun telah dikuasai pihak ke III namun perolehan barang (aset) telah diduga dari hasil kejahatan (korupsi), maka menurut UNCAC negara korban dapat melakukan perampasan atas barang (NCB) tanpa pemidanaan guna pemulihan atau pengembalian aset negara yang dicurinya, artinya bahwa diketahui adanya barang yang diduga hasil tindak kejahatan (korupsi) dapat dirampas oleh negara, meskipun si pelaku (koruptor) belum atau sedang dan atau bahkan sudah menjalani proses pidananya. Model yang demikian seharusnya dapat diterapkan dalam menyelesaikan kasus BLBI.

\footnotetext{
${ }^{30}$ Greenberg, Theodore S., Samuel, Linda M., et al. Stolen Asset Recovery, Good Practice Guide Untuk Perampasan Aset Tanpa Pemidanaan (Non-Conviction Based/NCB Asset Forfeiture), The World Bank, Washington DC 20433, USA, 2009, hlm. 1
} 
Namun, dalam kasus BLBI banyak pelaku yang kemudian tidak diproses pidananya dengan alasan kurang adanya bukti tindak kejahatannya, tetapi telah nyata adanya kerugian negara yang timbul akibat perbuatannya tersebut, maka seharusnya pemerintah dapat melakukan perampasan atas barang-barang (NCB) pelaku tanpa dilakukan pemidanaan, hal ini merupakan tindakan in rem terhadap harta benda, bukan terhadap orangnya. ${ }^{31}$

Menurut pendapat penulis, prosedur ini akan efektif terutama terhadap tindak pidana korupsi yang dilakukan atas dasar (sarat) dengan muatan politis, sehingga harus mengembalikan barang (uang atau dana) kepada negara yang menjadi korban, sebagaimana diatur dalam article 54 number (1) c UNCAC.

Sayangnya, meskipun Indonesia telah turut meratifikasi UNCAC (UU Anti Korupsi Sedunia), namun hingga saat ini belum diimplementasikan dengan maksimal, baik sebagai upaya pencegahan maupun sebagai upaya pemberantasan tindak pidana korupsi di Indonesia.

\section{Kendala Hukum yang menyebabkan berlarut-larutnya penyelesaian tindak pidana korupsi dalam kasus BLBI}

Kendala hukum secara Penal adalah: 1. masih adanya pengaruh muatan politik yang mempengaruhi dalam Penegakan hukumnya; 2. sistem hukumnya yang kaku, sehingga tidak dapat menyelesaikan tindak korupsi yang sifatnya cair, dinamis, terselubung dan terorganisasi; 3 . kurang maksimalnya pemerintah dalam pengejaran aset negara yang berada di luar negeri.

Kendala hukum secara Non- Penal adalah: 1. penyelesaian melalui gugatan perdata menemui kendala antara lain: a. Prosedurnya lama, adversarial, biaya mahal. b. Untuk menentukan aset dari hasil korupsi yang dilakukan Tergugat sangat sulit (karena kepandaian mengalihkan wujud/pencucian uang). c. mencari kebenaran formil, sehingga sulit pembuktiannya. d. Muncul kekhawatiran terhadap perilaku para penegak hukumnya sendiri. 2. dalam pelaksanaannya, a. belum memaksimalkan ketentuan UNCAC tentang aset recovery.b. belum memaksimalkan prinsip litigasi multiyurisdiksi, artinya gugatan perdata dapat dilakukan oleh suatu negara yang menjadi korban (victim countries) dari tindak pidana korupsi yang diajukan melalui negara lain. c. kurang maksimal terhadap pengawasan yang

\footnotetext{
${ }^{31}$ Ibit.,hlm.15.
} 
berkelanjutan terhadap para penegak hukum. d. belum adanya pengakuan mekanisme ADR, Retoratif justice sebagai sarana penyelesaian perkara tindak pidana korupsi. e. Pengetahuan dan keberanian para penegak hukum masih kurang untuk menerapkan undang-undang secara elastis sesuai dengan azas mamfaatdan masih berpihak secara kaku kepada adanya aturan undang-undang (sebagai corong undang-undang)

\section{Penutup}

Pemberantasan korupsi di Indonesia telah dilakukan dengan berbagai pembaharuan hukum dan telah pula diimplentasikan oleh para penegak hukum (Polisi, Jaksa, Hakim dan Advokat), namun upaya pemberantasan tindak pidana korupsi melalui pembaharuan hukum pidana tersebut belum menyelesaikan atau belum membuat para koruptor menjadi jera.

Pada prinsipnya pemanfaatan hukum perdata baik litigasi maupun non litigasi(negosiasi atau mediasi) dalam penyelesaian tindak pidana korupsi BLBI dapat dilakukan dalam rangka pengembalian, pemulihan, dan perampasan aset negara yang dicuri oleh para koruptor, baik yang berada di Indonesia, maupun yang dibawa ke luar negeri atau yang di transfer ke luar negeri.

Kendala hukum yang menyebabkan berlarut-larutnya penyelesaian tindak pidana korupsi dalam kasus BLBI antara lain: 1. cara kerja sistem hukum pidananya bersifat formal-legalistik-positifistik, 2. sulit pembuktiannya, 3. belum adanya kerjasama (perjanjian extradisi) dengan semua negara tempat aset berada, 5 . belum diterapkannya pembuktian terbalik secara penuh, 6 . koruptor dan barangnya dibawa atau ditransfer keluar negeri, 7. adanya perbedaan sistem hukum antara Indonesia dengan negara lainnya, sehingga dapat menimbulkan perselisihan penerapan hukumnya, 8. adanya keengganan dari obligator BLBI mengembalikan pinjamannya karena tetap diancam secara pidana sesaui dengan Pasal 4 UUPTPK.

Indonesia harus segera melakukan harmonisasi peraturan nasional dengan peraturan internasional, untuk menyeragamkan visi dan misi serta upaya memperkuat kerja sama untuk dapat saling membantu dalam pengembalian aset negara atau pemulihan aset yang dikorupsi (to sthrengten international cooperation in asset recovery).

Melakukan revisi Pasal 4 UUPTPK No. 31 Tahun 1999 jo No.20 Tahun 2001 untuk memacu pengembalian kerugian keuangan negara hasil korupsi dalam kasus 
korupsi tertentu,terutama yang ada hubungan perdata seperti kasus BLBI,dengan mengacu kepada Article 31 Chapter V UNCAC yang mengatur percepatan process Stolen Asset Recopery (StAR) dan Perampasan Aset Non-Conviction Based (NCB) atau tanpa pemidanaan.

\section{Daftar Pustaka}

Hamzah, Andi, Korupsi di Indonesia, Masalah dan Pemecahannya, Gramedia Pustaka Utama, Jakarta, 1991.

Cross Default dan Cross Collateral Sebagai Upaya Penyelasaian Kredit Bermasalah, Bandung,Refika Aditama, 2004.

Nawawi Arief, Barda, Pembaharuan Hukum Pidana (Dalam Perspektif Kajian Perbandingan), Citra Aditya Bhakti, Bandung, , 2005.

Greenberg,Theodore S,Samuel,LindaM., Stolen Asset Rocovery, GOOD practice Guide,The World Bank,Washington DC 20433,USA, , 2009

Seno Adji, Indriyanto, Korupsi Kebijakan Aparatur NegaraEHukum Pidana,CV.Diadit Media,Jakarta, 2007.

Bentham,Jeremy, Teori Perundang-undangan, Nusamedia, Bandung, 2006.

Ibrahim,Johanes, Bank Sebagai Lemabaga Intermediasi Dalam Hukum Positif, Utomo, Bandung, 2004.

Emong Sapardjaja, Komariah, Ajarab Sifat Melawan Hukum Materiil Dalam Hukum Pidana Indonesia, PT. Alumni, Bandung, 2002.

Loqman,Lobby, Beberapa Ikhwal Dalam Undang-Undang No. 3 Tahun 1971 Tentang Pemberantasan Tindak Pidana Korupsi, Datacom, Jakarta, 1991.

Nigel Walker, Sentencing in a rational society, New York, 1972.

Atmasasmita, Romli, Sekitar Masalah Korupsi, Mandar Maju, Jakarta, 2004.

Rahardjo, Satjipto, Hukum dan Masyarakat, Angkasa, Bandung, 1979.

Undang-Undang Nomor 20 Tahun 2001 Tentang Perubahan Atas Undang-Undang No. 31 Tahun 1999 Tentang Pemberantasan Tindak Pidana Korupsi

Undang-Undang Nomor 31 Tahun 1999 Tentang Pemberantasan Tindak Pidana Korupsi

Undang-Undang Nomor 7 Tahun 2006 Tentang Pengesahan United Nations Convention Against Corruption, 2003.

Inpres No. 8 Tahun 2008 tentang Release And Discharge.

Konvensi Perserikatan Bangsa-Bangsa Mengenai Korupsi, 2003, United Nations Convenstion Against Corruption, 2003. 
Atmasasmita, Romli, 2006, "Strategi dan Kebijakan Pemberantasan Korupsi Pasca Konvensi PBB Menentang Korupsi Tahun 2003: Melawan Kejahatan Korporasi", Paper, Jakarta,

"Strategi dan Kebijakan Hukum dalam Pemberantasan Korupsi Melawan Kejahatan Korporasi di Indonesia: Membentuk Ius Constituendum Pasca Ratifikasi Konvensi PBB Menentang Korupsi Tahun 2003", Paper, Jakarta, 2006.

,"Indonesia Pasca Konvensi PBB Menentang Korupsi", Paper, Jakarta, 2006.

Priyatno, Dwidja, Jurnal RESTORASI, edisi VIII/volume III, 2007.

Rahardjo, Satjipto, “Modernisasi dan Perembangan Kesadaran Hukum Masyarakat”, Jurnal Masalah-masalah Hukum, FH Undip, No.1-6 Tahun X, 1980.

Rachmadi, Takdir, dalam Basuki Rekso Wibowo, Pidato Pengukuhan jabatan Guru Besar Di Bidang ilmu Hukum: Menyelesaiakan Sengketa Bisnis Di Luar Pengadilan, Universitas Airlangga, 17 Desember 2005.

Kompas, Perlu Mekanisme Atasi Hambatan, 27 Oktober 2007.

Kompas, Jakarta, 2006.

http://www.komisihukum.go.id/index.php?option=com_content\&view= article $\& i d=83 \% 3$ Apendapat-khn-tentang-stolen-asset-recoverystarAnitiative \& catid= 37\%3Aopini\&Itemid=61\&lang $=$ in

http:// www.hukumonline.com/berita/baca/hol17428/lagi-putusan-ma-salahketik

http://www.jurnas.com/news/25205/Koruptor Rp25 Juta Bisa Dibebaskan// Nasional/Hukum

Sudarto dalam Agus Rahajo, Perkembangan Ajaran Sifat Melawan Hukum Material dalam Hukum Pidana Indonesia, http://www.unsoed.ac.id/newcmsfak/UserFiles/ File/HUKUM/Agus. 